\title{
Examination of the role of
}

methylenetetrahydrofolate reductase in incorporation of methyltetrahydrofolate into cellular metabolism

\author{
JACALYN M. GREEN, DAVID P. BALLOU, AND ROWENA G. MATTHEWS \\ Department of Biological Chemistry and Biophysics Research Division, The University of Michigan, Ann Arbor, \\ Michigan 48109, USA
}

\begin{abstract}
Most mammalian cells receive exogenous folate from the bloodstream in the form of 5-methyltetrahydropteroylmonoglutamate $\left(\mathrm{CH}_{3}-\mathrm{H}_{4} \mathrm{PteGlu}_{1}\right)$. Because this folate derivative is a very poor substrate for folylpolyglutamate synthetase, the enzyme that adds glutamyl residues to intracellular folates, $\mathrm{CH}_{3}-\mathrm{H}_{4} \mathrm{PteGlu}_{1}$ must first be converted to tetrahydropteroylmonoglutamate $\left(\mathrm{H}_{4} \mathrm{PteGlu}_{1}\right), 10$-formyltetrahydropteroylmonoglutamate (CHO- $\mathrm{H}_{4}$ PteGlu $\left.)_{1}\right)$, or dihydrofolate $\left(\mathrm{H}_{2}\right.$ folate), which are excellent substrates for folylpolyglutamate synthetase. Polyglutamylation is required both for retention of intracellular folates and for efficacy of folates as substrates for most folate-dependent enzymes. Two enzymes are known that will react with $\mathrm{CH}_{3}-\mathrm{H}_{4} \mathrm{PteGlu}$ in vitro, methylenetetrahydrofolate reductase and methyltetrahydrofolate-homocysteine methyltransferase (cobalamindependent methionine synthase). These studies were performed to assess the possibility that methylenetetrahydrofolate reductase might catalyze the conversion of $\mathrm{CH}_{3}-\mathrm{H}_{4} \mathrm{PteGlu}_{1}$ to $\mathrm{CH}_{2}-\mathrm{H}_{4} \mathrm{PteGlu}_{1}$. $\mathrm{CH}_{2}-\mathrm{H}_{4} \mathrm{PteGlu}_{1}$ is readily converted to $\mathrm{CHO}-\mathrm{H}_{4} \mathrm{PteGlu}_{1}$ by the action of methylenetetrahydrofolate dehydrogenase/methenyltetrahydrofolate cyclohydrolase, and these enzyme activities show very little preference for folylpolyglutamate substrates as compared with folylmonoglutamates. We conclude from in vitro studies of the enzyme that methylenetetrahydrofolate reductase cannot convert $\mathrm{CH}_{3}-\mathrm{H}_{4} \mathrm{PteGlu}_{1}$ to $\mathrm{CH}_{2}-\mathrm{H}_{4} \mathrm{PteGlu}_{1}$ under physiological conditions and that uptake and retention of folate will be dependent on methionine synthase activity. - Green, J. M.; Ballou, D. P.; Matthews, R. G. Examination of the role of methylenetetrahydrofolate reductase in incorporation of methyltetrahydrofolate into cellular metabolism. FASEB J. 2: 42-47; 1988.
\end{abstract}

Key Words: methyltetrahydrofolate $\cdot$ folylpolyglutamate $\cdot$ methylenetetrahydrofolate reductase $\cdot$ folate uptake
INTRACELLULAR FOLATES ARE PRESENT predominantly as polyglutamate derivatives with a chain of glutamyl residues in $\gamma$ linkage. The polyglutamate tail is required for intracellular retention of folates. It also constitutes an important recognition site for folatedependent enzymes; many such enzymes exhibit much lower $K_{\mathrm{m}}$ values for folate polyglutamate substrates than for the corresponding monoglutamates. Most mammalian cells receive exogenous folate as the monoglutamate of 5-methyltetrahydrofolate $\left(\mathrm{CH}_{3}-\mathrm{H}_{4} \mathrm{PteGlu}_{1}\right){ }^{1}$ the form of folate that is transported in the bloodstream. Tetrahydropteroylmonoglutamate $\left(\mathrm{H}_{4} \mathrm{PteGlu}_{1}\right)$, 7,8-dihydropteroylmonoglutamate $\left(\mathrm{H}_{2} \mathrm{PteGlu}_{1}\right)$, and 10 formyltetrahydropteroylmonoglutamate $\left(\mathrm{CHO}-\mathrm{H}_{4} \mathrm{PteGlu}_{1}\right)$ are all excellent substrates for folylpolyglutamate synthetase (EC 6.3.2.17) from pig liver (1). In contrast, $\mathrm{CH}_{3}-\mathrm{H}_{4}$ PteGlu $_{1}$ is a very poor substrate for folylpolyglutamate synthetase, the enzyme that adds glutamyl residues to intracellular folate derivatives (1). Incorporation of $\mathrm{CH}_{3}-\mathrm{H}_{4} \mathrm{PteGlu}_{1}$ into cellular metabolism therefore requires conversion of $\mathrm{CH}_{3}-\mathrm{H}_{4} \mathrm{PteGlu}_{1}$ into $\mathrm{H}_{4} \mathrm{PteGlu}_{1}$ or 5,10 -methylenetetrahydropteroylmonoglutamate $\left(\mathrm{CH}_{2}-\mathrm{H}_{4} \mathrm{PteGlu}_{1}\right)$, with subsequent conversion of $\mathrm{CH}_{2}-\mathrm{H}_{4} \mathrm{PteGlu}_{1}$ into $\mathrm{H}_{4} \mathrm{PteGlu}_{1}, \mathrm{H}_{2} \mathrm{PteGlu}_{1}$, or $\mathrm{CHO}_{2} \mathrm{H}_{4} \mathrm{PteGlu}_{1}$. The methylenetetrahydrofolate dehydrogenase/methenyltetrahydrofolate cyclohydrolase activities (EC 1.5.1.5/EC 3.5.4.9) of the trifunctional enzyme from pig liver, which catalyzes reactions $3 \mathrm{~A}$, $3 \mathrm{~B}$, and $3 \mathrm{C}$ of Fig. 1, show a very low discrimination between polyglutamate and monoglutamate substrates

\footnotetext{
'Abbreviations: $\mathrm{CH}_{3}-\mathrm{H}_{4}$ PteGlu, 5-methyltetrahydropteroylpolyglutamate with $n$ glutamyl residues; $\mathrm{CH}_{2}-\mathrm{H}_{4}$ PteGlu $, 5,10$-methylenetetrahydropteroylpolyglutamate with $n$ glutamyl residues; $\mathrm{H}_{4} \mathrm{PteGlu}$, tetrahydropteroylpolyglutamate with $n$ glutamyl residues; $\mathrm{CHO}-\mathrm{H}_{4} \mathrm{PteGlu}$, 10 -formyltetrahydropteroylpolyglutamate with $\mathrm{n}$ glutamyl residues; $\mathrm{H}_{2} \mathrm{PteGlu}_{\mathrm{n}}$, 7,8-dihydropteroylpolyglutamate with $n$ glutamyl residues; $\mathrm{H}_{2}$ folate, dihydrofolate; $\mathrm{CH}_{3}-\mathrm{H}_{4}$ folate, 5-methyltetrahydrofolate; $\mathrm{CH}_{2}-\mathrm{H}_{4}$ folate, 5,10-methylenetetrahydrofolate; AdoMet, $S$-adenosylmethionine; AdoHCy, $S$-adenosylhomocysteine.
} 


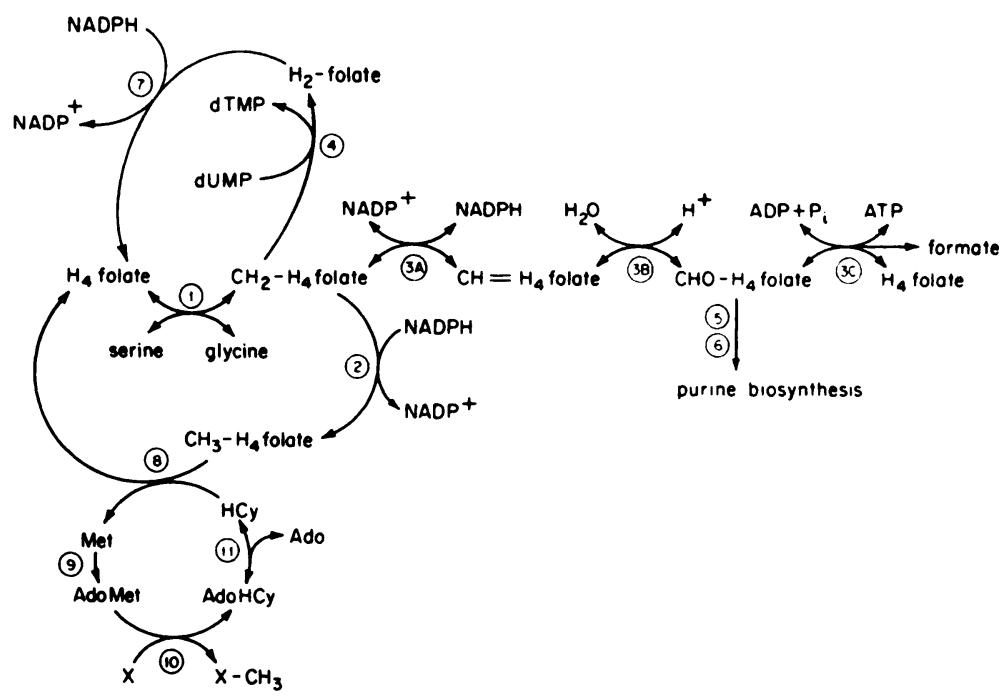

Figure 1. Outline of the major folate-dependent pathways in mammalian cells. The enzymes involved are: 1) serine hydroxymethyltransferase, 2) methylenetetrahydrofolate reductase, 3) the trifunctional enzyme with methylenetetrahydrofolate dehydrogenase (3A), methenyltetrahydrofolate cyclohydrolase (3B), and formyltetrahydrofolate synthetase (3C) activities, 4) thymidylate synthase, 5) glycinamide ribonucleotide transformylase, 6) aminoimidazolecarboxamide ribonucleotide transformylase, 7 ) dihydrofolate reductase, 8 ) methyltetrahydrofolate-homocysteine methyltransferase (methionine synthase), 9) adenosylmethionine synthetase, 10) adenosylmethioninedependent methyltransferases, and 11) adenosylhomocysteine hydrolase.

and could readily interconvert $\mathrm{CH}_{2}-\mathrm{H}_{4} \mathrm{PteGlu}_{1}$ and CHO- $\mathrm{H}_{4}$ PteGlu $_{1}$ (2).

The two mammalian enzymes known to react with 5-methyltetrahydrofolate $\left(\mathrm{CH}_{3}-\mathrm{H}_{4}\right.$ folate $)$ in vitro are methyltetrahydrofolate-homocysteine methyltransferase (cobalamin-dependent methionine synthase, EC 2.1.1.13) and methylenetetrahydrofolate reductase (EC 1.5.1.20). These studies were initiated to determine whether methylenetetrahydrofolate reductase from pig liver can convert $\mathrm{CH}_{3}-\mathrm{H}_{4} \mathrm{PteGlu}_{1}$ to $\mathrm{CH}_{2}-\mathrm{H}_{4} \mathrm{PteGlu}_{1}$ under physiological conditions.

Methylenetetrahydrofolate reductase catalyzes the following oxidoreductase reactions:

$\mathrm{NADPH}+\mathrm{CH}_{2}-\mathrm{H}_{4}$ folate $\rightarrow \mathrm{NADP}^{+}+\mathrm{CH}_{3}-\mathrm{H}_{4}$ folate

$\mathrm{CH}_{3}-\mathrm{H}_{4}$ folate + menadione $\rightleftharpoons \mathrm{CH}_{2}-\mathrm{H}_{4}$ folate + menadiol (2)

Reaction 1 commits tetrahydrofolate-bound one-carbon units to the pathway that generates methyl groups to support $S$-adenosylmethionine (AdoMet)-dependent methylations. This pathway is shown in Fig. 1 and involves subsequent transfer of the methyl group of $\mathrm{CH}_{3}-\mathrm{H}_{4}$ folate to homocysteine to form methionine (catalyzed by methionine synthase) and adenylation of methionine to form AdoMet. The cellular ratio of AdoMet to $S$-adenosylhomocysteine (AdoHCy) controls the $\mathrm{NADPH} / \mathrm{CH}_{2}-\mathrm{H}_{4}$ folate oxidoreductase activity of methylenetetrahydrofolate reductase (3). AdoMet serves as an allosteric inhibitor of this reaction, whereas AdoHCy competes with AdoMet at the binding site; AdoHCy does not itself cause inhibition.

Methylenetetrahydrofolate reductase is a flavoprotein; the enzyme-bound FAD is alternately reduced by NADPH and reoxidized by 5,10-methylenetetrahydrofolate $\left(\mathrm{CH}_{2}-\mathrm{H}_{4}\right.$ folate) in catalysis. The reaction of the reduced flavin with $\mathrm{CH}_{2}-\mathrm{H}_{4}$ folate is a fully reversible half-reaction $\left(\Delta G^{01}=-0.5 \mathrm{kcal} / \mathrm{mol}\right)$. In contrast, the reduction of the enzyme-bound flavin by NADPH is irreversible because of the large standard free energy decrease $\left(\Delta G^{01}=-9 \mathrm{kcal} / \mathrm{mol}\right)$ and the high NADPH/ $\mathrm{NADP}^{+}$ratio in the cytoplasm (4). Although reversal of reaction 1 is virtually impossible, methylenetetrahydrofolate reductase can catalyze oxidation of $\mathrm{CH}_{3}-\mathrm{H}_{4}$ folate in the presence of a high potential electron acceptor such as menadione (3) as shown in $E q$. 2, although NADPH would be expected to inhibit this reaction by competing with $\mathrm{CH}_{3}-\mathrm{H}_{4}$ folate for the oxidized form of the enzyme.

The third reaction catalyzed by methylenetetrahydrofolate reductase is the exchange of reducing equivalents between $\mathrm{CH}_{3}-\mathrm{H}_{4}$ folate and $\mathrm{CH}_{2}-\mathrm{H}_{4}$ folate (5). If such an exchange occurs between monoglutamate and polyglutamate substrates, as shown in $E q .3$, it could constitute a significant pathway for conversion of $\mathrm{CH}_{3}$ $\mathrm{H}_{4} \mathrm{PteGlu}_{1}$ from the blood into $\mathrm{CH}_{2}-\mathrm{H}_{4} \mathrm{PteGlu}_{1}$.

$$
\begin{aligned}
& \mathrm{CH}_{3}-\mathrm{H}_{4} \mathrm{PteGlu}_{1}+\mathrm{CH}_{2}-\mathrm{H}_{4} \mathrm{PteGlu}_{6} \\
& \quad \rightleftharpoons \mathrm{CH}_{2}-\mathrm{H}_{4} \mathrm{PteGlu}_{1}+\mathrm{CH}_{3}-\mathrm{H}_{4} \text { PteGlu }_{6}
\end{aligned}
$$

We have shown that pig liver methionine synthase exhibits a strong preference for hexaglutamate $\mathrm{CH}_{3}$ $\mathrm{H}_{4}$ folate as compared with the monoglutamate (6), and so catalysis of reaction 3 would also provide a significantly better substrate for methionine synthase. In this way methylenetetrahydrofolate reductase could be important in cellular uptake and retention of folate. Critical to an assessment of the physiological role of methylenetetrahydrofolate reductase in incorporation of $\mathrm{CH}_{3}-\mathrm{H}_{4}$ folate into cellular metabolism is a knowledge of the effects of NADPH and AdoMet on reactions 2 and 3 . If these metabolites, which are present in high concentrations in mammalian cells, 
inhibit the conversion of $\mathrm{CH}_{3}-\mathrm{H}_{4} \mathrm{PteGlu}_{1}$ to $\mathrm{CH}_{2}$ $\mathrm{H}_{4} \mathrm{PteGlu}_{1}$, then a physiological role for methylenetetrahydrofolate reductase in catalyzing this conversion is unlikely. The experiments to be described provide evidence that physiological concentrations of AdoMet and/or NADPH severely inhibit reactions 2 and 3 in vitro.

\section{RESULTS AND DISCUSSION}

Effect of AdoMet on half-reactions necessary to support enzyme-mediated exchange of reducing equivalents between $\mathrm{CH}_{2}-\mathrm{H}_{4}$ folate and $\mathrm{CH}_{3}-\mathrm{H}_{4}$ folate

The absorbance at $450 \mathrm{~nm}$ of the enzyme-bound FAD of methylenetetrahydrofolate reductase provides a convenient probe of the oxidation state of the enzyme. This permits us to measure the reductive and oxidative halfreactions by stopped-flow techniques. The reduction of methylenetetrahydrofolate reductase by $100 \mu \mathrm{M} \mathrm{CH}_{3}$ $\mathrm{H}_{4} \mathrm{PteGlu}_{1}$ in the presence and absence of AdoMet is shown in Fig. 2. Both curves are monophasic; the firstorder rate constant for reduction of the enzyme by saturating $\mathrm{CH}_{3}-\mathrm{H}_{4} \mathrm{PteGlu}_{1}$ is $6.1 \mathrm{~s}^{-1}$. In the presence of added AdoMet this value is $0.002 \mathrm{~s}^{-1}$. Thus the rate of reduction of the enzyme in the presence of AdoMet is 3000 -fold slower than in its absence. Figure 3 shows the oxidation of reduced methylenetetrahydrofolate reductase by saturating $\mathrm{CH}_{2}-\mathrm{H}_{4} \mathrm{PteGlu}_{1}$. In the absence of AdoMet, this reaction is clearly biphasic. The fast phase, which accounts for $67 \%$ of the change in ab-

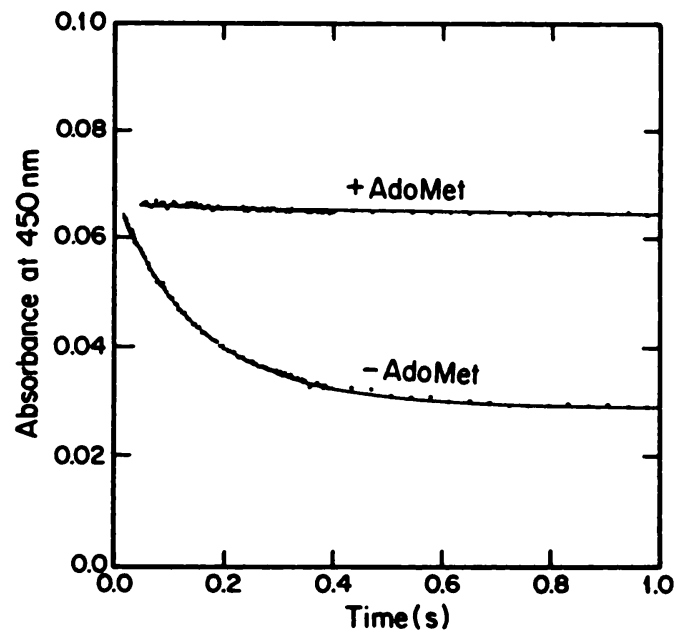

Figure 2. Stopped-flow measurement of the reduction of methylenetetrahydrofolate reductase by $\mathrm{CH}_{3}-\mathrm{H}_{4} \mathrm{PteGlu}$ in the presence and absence of $110 \mu \mathrm{M}$ AdoMet. Methylenetetrahydrofolate reductase was purified from pig liver by a method previously described (7). AdoMet, (6R)- $\mathrm{H}_{4}$ folate, and $(6 S)-\mathrm{CH}_{3}-\mathrm{H}_{4}$ folate were prepared and/or purified as described before $(8,9)$. Buffered enzyme, $6 \mu \mathrm{M}$ in FAD, was mixed with an equal volume of buffer containing 100 $\mu \mathrm{M}(6 S)-\mathrm{CH}_{3}-\mathrm{H}_{4} \mathrm{PteGlu}_{1}$ added as $(6-\mathrm{R}, S)-\mathrm{CH}_{3}-\mathrm{H}_{4} \mathrm{PteGlu}$. [All experiments were conducted in $50 \mathrm{mM}$ potassium phosphate buffer, pH 7.2, $0.3 \mathrm{mM}$ EDTA, and 10\% glycerol (wt/vol).] Absorbance was monitored at $450 \mathrm{~nm}$ in the 2-cm pathlength of a stopped-flow apparatus, which was maintained under anaerobic conditions at $25^{\circ} \mathrm{C}$. Anaerobiosis was achieved and maintained as described before (see ref 5).

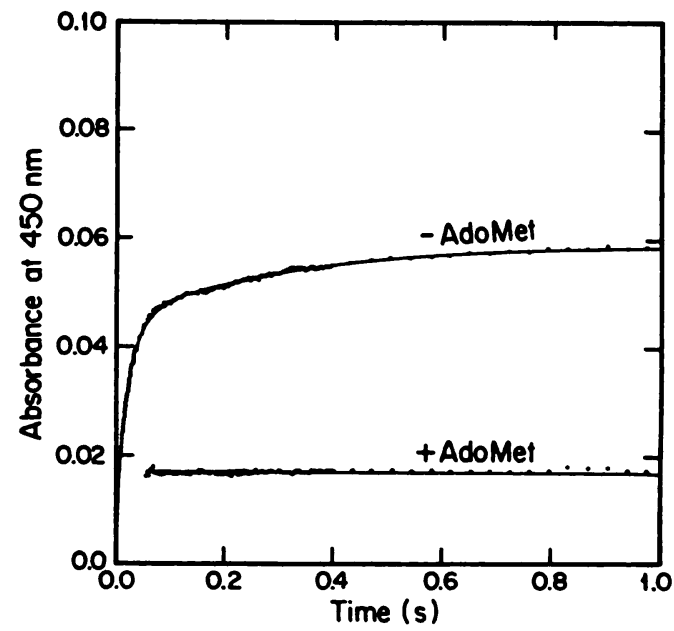

Figure 3. Stopped-flow measurement of the oxidation of reduced methylenetetrahydrofolate reductase by $\mathrm{CH}_{2}-\mathrm{H}_{4} \mathrm{PteGlu}{ }_{1}$ in the presence or absence of $110 \mu \mathrm{M}$ AdoMet. Buffered enzyme, $6 \mu \mathrm{M}$ in FAD, was anaerobically titrated with a stoichiometric amount of NADPH to form reduced enzyme. Reduced enzyme was then mixed with an equal volume of buffer containing $100 \mu \mathrm{M}(6 R)$ $\mathrm{CH}_{2}-\mathrm{H}_{4} \mathrm{PteGlu}_{1}$, added as $(6-R, S)-\mathrm{CH}_{2}-\mathrm{H}_{4} \mathrm{PteGlu}$. [All experiments were conducted in $50 \mathrm{mM}$ potassium phosphate buffer, $\mathrm{pH}$ 7.2, $0.3 \mathrm{mM}$ EDTA, and $10 \%$ glycerol (wt/vol).] $\mathrm{CH}_{2}-\mathrm{H}_{4} \mathrm{PteGlu}_{1}$ was prepared by preincubating $13 \mathrm{mM}$ formaldehyde and $200 \mu \mathrm{M}$ $(6 R, S)-\mathrm{H}_{4}$ folate together in buffer containing $26 \mathrm{mM}$ 2-mercaptoethanol for $10 \mathrm{~min}$ before the experiment.

sorbance, is characterized by a first-order rate constant of $47 \mathrm{~s}^{-1}$, and the value calculated for the slow phase is $3 \mathrm{~s}^{-1}$. In the presence of AdoMet, the oxidation of reduced enzyme by $100 \mu \mathrm{M} \mathrm{CH} \mathrm{CH}_{2}-\mathrm{H}_{4} \mathrm{PteGlu}_{1}$ is apparently monophasic for $600 \mathrm{~s}$; the rate constant for this half-reaction is $0.0037 \mathrm{~s}^{-1}$.

We conclude that AdoMet is a potent inhibitor of the transfer of reducing equivalents between the enzymebound flavin of methylenetetrahydrofolate reductase and folate substrates.

\section{Effects of AdoMet and NADPH on $\mathrm{CH}_{3}-\mathrm{H}_{4}$ folate/ menadione oxidoreductase activity}

Although menadione is not a physiological electron acceptor we have assumed that inhibition studies of the $\mathrm{CH}_{3}-\mathrm{H}_{4}$ folate/menadione oxidoreductase activity could provide insight into the possibility that methylenetetrahydrofolate reductase might catalyze a similar reduction of an unknown high-potential electron acceptor in the cell, with concomitant oxidation of $\mathrm{CH}_{3}-\mathrm{H}_{4} \mathrm{PteGlu}$ to $\mathrm{CH}_{2}-\mathrm{H}_{4} \mathrm{PteGlu}_{1}$. For these studies we used two methods of measuring $\mathrm{CH}_{3}-\mathrm{H}_{4}$ folate/menadione oxidoreductase activity: spectrophotometric measurement and radiochemical assay. The spectrophotometric method offers the advantages of a continuous assay; however, it is useful only over a limited range of $\mathrm{CH}_{3}-\mathrm{H}_{4}$ folate concentrations. Concentrations of $\mathrm{CH}_{3}-\mathrm{H}_{4}$ folate below $5 \mu \mathrm{M}$ produce nonlinear initial rates owing to substrate depletion during the assay, whereas concentrations above $70 \mu \mathrm{M}$ possess too much background absorbance for spectrophotometric measurement. The spectrophotometric assay was used to measure the $K_{\mathrm{m}}$ for $\mathrm{CH}_{3}-\mathrm{H}_{4} \mathrm{PteGlu}_{1}(33 \mu \mathrm{M}$, data not 
shown). The radiochemical assay was used to measure the $K_{\mathrm{m}}$ for $\mathrm{CH}_{3}-\mathrm{H}_{4} \mathrm{PteGlu}_{6}(1.9 \mu \mathrm{M}$, data not shown) and to determine the relative values for $V_{\max }$ with $\mathrm{CH}_{3}$ $\mathrm{H}_{4} \mathrm{PteGlu}_{1}$ (set at 1.0 ) and $\mathrm{CH}_{3}-\mathrm{H}_{4} \mathrm{PteGlu}_{6}$ (measured as $0.52)$. For reaction 2 to be of physiological significance, $\mathrm{CH}_{3}-\mathrm{H}_{4} \mathrm{PteGlu}_{1}$, which is present at very low concentrations (1), would be required to compete successfully with $\mathrm{CH}_{3}-\mathrm{H}_{4}$ folate polyglutamates, which are present at much higher concentrations, for oxidation by methylenetetrahydrofolate reductase. The magnitude of the $V_{\max } / K_{\mathrm{m}}$ ratio for a substrate is usually proportional to the effectiveness of that substrate in competition with other substrates. Our studies show that $V_{\max } / K_{\mathrm{m}}$ for $\mathrm{CH}_{3}$ $\mathrm{H}_{4} \mathrm{PteGlu}_{6}$ is 11.5 -fold higher than $V_{\max } / K_{\mathrm{m}}$ for $\mathrm{CH}_{3}$ $\mathrm{H}_{4} \mathrm{PteGlu}_{1}$. These results suggest that intracellular $\mathrm{CH}_{3}-\mathrm{H}_{4}$ folate polyglutamates may significantly inhibit the oxidation of $\mathrm{CH}_{3}-\mathrm{H}_{4} \mathrm{PteGlu}_{1}$ by methylenetetrahydrofolate reductase.

The radiochemical assay was also used to measure the effect of NADPH on $\mathrm{CH}_{3}-\mathrm{H}_{4} \mathrm{PteGlu}_{1} /$ menadione oxidoreductase activity in the presence or absence of AdoMet. Either NADPH $(100 \mu \mathrm{M})$ or AdoMet $(50 \mu \mathrm{M})$ inhibits the reactions; when they are included together in the preincubation, inhibition is virtually complete (data not shown). Thus, the presence of NADPH does not protect the $\mathrm{CH}_{3}-\mathrm{H}_{4}$ folate/menadione oxidoreductase activity of the enzyme from inhibition by AdoMet.

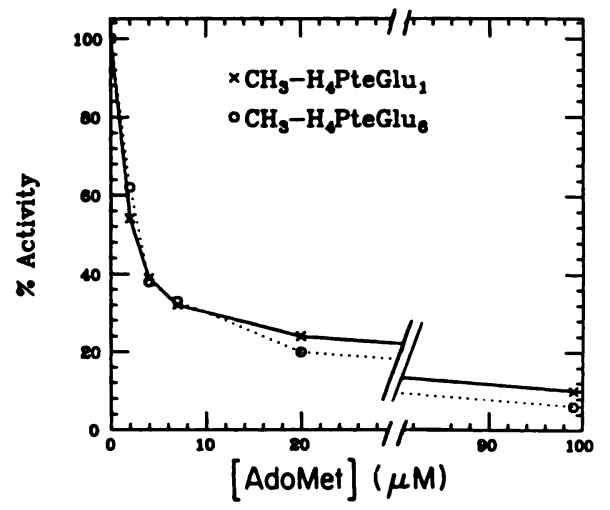

Figure 4. Comparison of the effect of AdoMet on the $\mathrm{CH}_{3}$ $\mathrm{H}_{4} \mathrm{PteGlu}_{1} /$ menadione and $\mathrm{CH}_{3}-\mathrm{H}_{4} \mathrm{PteGlu}_{6} /$ menadione oxidoreductase activities of methylenetetrahydrofolate reductase. Cuvets $(1 \mathrm{ml})$ containing buffer, $\mathrm{CH}_{3}-\mathrm{H}_{4}$ folate, and menadione were placed in the sample and reference beams of a Cary 118 recording spectrophotometer; the back cuvet contained no enzyme, and the reaction in the front cuvet was initiated with substrate. Assay mixtures containing buffer, methylenetetrahydrofolate reductase, and varying amounts of AdoMet were preincubated for $10 \mathrm{~min}$ at $25^{\circ} \mathrm{C}$. [All experiments were conducted in $50 \mathrm{mM}$ potassium phosphate buffer, $\mathrm{pH} 7.2,0.3$ $\mathrm{mM}$ EDTA, and $10 \%$ glycerol (wt/vol).] (6S)- $\mathrm{CH}_{3}-\mathrm{H}_{4}$ folate $(25 \mu \mathrm{M})$ and menadione $(121 \mu \mathrm{M})$ were quickly added to initiate the reaction, and the increase in absorbance at $312 \mathrm{~nm}$ was monitored; the change in absorbance at $312 \mathrm{~nm}$ represents the combined effects of $\mathrm{CH}_{3}$ $\mathrm{H}_{4}$ folate and menadione being converted to $\mathrm{CH}_{2}-\mathrm{H}_{4}$ folate and menadiol $\left(\Delta \epsilon=8300 \mathrm{M}^{-1} \mathrm{~cm}^{-1}\right)$. Blank rates caused by the reaction of residual 2-mercaptoethanol with menadione were subtracted; 2-mercaptoethanol was present to stabilize the $\mathrm{CH}_{3}-\mathrm{H}_{4}$ folate stocks, and the concentration in the final reaction mixture was less than $1 \mathrm{mM}$. Assays were performed in duplicate or triplicate and the averaged data are shown. Activities are expressed as the percentage of the activity observed in the absence of AdoMet.

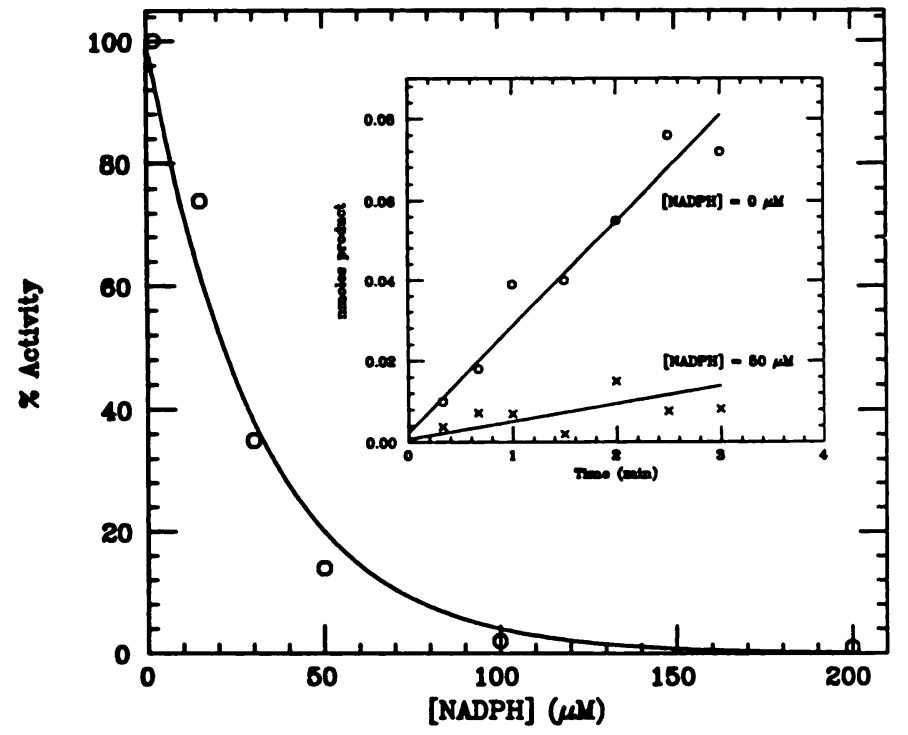

Figure 5. Effect of NADPH on the exchange of reducing equivalents between $\mathrm{CH}_{3}-\mathrm{H}_{4} \mathrm{PteGlu}_{1}$ and $\mathrm{CH}_{2}-\mathrm{H}_{4} \mathrm{PteGlu}_{6}$. Assay mixtures, 0.4 $\mathrm{ml}$, contained buffer, $20 \mathrm{mM}$ 2-mercaptoethanol, $3 \mathrm{mM}$ formaldehyde, $50 \mu \mathrm{M}$ tritiated $(6 S)-\mathrm{CH}_{3}-\mathrm{H}_{4} \mathrm{PteGlu}_{1}$, and $25 \mu \mathrm{M} \mathrm{H}_{4} \mathrm{PteGlu}_{1}$. [All experiments were conducted in $50 \mathrm{mM}$ potassium phosphate buffer, pH 7.2, $0.3 \mathrm{mM}$ EDTA, and $10 \%$ glycerol (wt/vol).] The $\left[{ }^{3} \mathrm{H}\right] \mathrm{CH}_{3}-\mathrm{H}_{4} \mathrm{PteGlu}_{1}$ had a specific radioactivity of $68,000 \mathrm{dpm} / \mathrm{nmol}$. Assays were initiated by the addition of enzyme, and were heatquenched at $98^{\circ} \mathrm{C}$ for $5 \mathrm{~min}$ after addition of $1.25 \mathrm{ml}$ of dimedone in $1 \mathrm{M}$ sodium acetate, $\mathrm{pH} 4.5$. Samples were cooled on ice and the dimedone-formaldehyde complex was extracted with toluene and counted in organic counting scintillant (Amersham, Arlington Heights, IL). Blanks containing no enzyme were subtracted from the other values for each set. The primary data of disintegrations per minute ${ }^{3} \mathrm{H}$ in product vs. time for each concentration of NADPH were fitted by linear regression. Slopes of these lines were used to calculate the percent activity relative to that observed with no NADPH added; the percent activity remaining is plotted vs. the concentration of NADPH present in the assay.

Figure 4 shows the effect of AdoMet on $\mathrm{CH}_{3}-\mathrm{H}_{4}$ folate/ menadione oxidoreductase activity. AdoMet inhibits $\mathrm{CH}_{3}-\mathrm{H}_{4}$ folate/menadione oxidoreductase activity with either monoglutamyl or hexaglutamyl substrates. The effect of AdoMet on $\mathrm{CH}_{3}-\mathrm{H}_{4}$ folate/menadione oxidoreductase activity is similar to its effect on NADPH/ menadione oxidoreductase activity (10). Half-maximal inhibition of NADPH/menadione oxidoreductase activity measured under the same conditions was seen at 2-3 $\mu \mathrm{M}$, whereas it occurs at $3 \mu \mathrm{M}$ with the $\mathrm{CH}_{3}-\mathrm{H}_{4}$ folate/ menadione oxidoreductase reaction. The degree of inhibition seen at $100 \mu \mathrm{M}$ AdoMet is, however, less than that seen in the stopped-flow study shown in Fig. 2, and may indicate that the presence of $\mathrm{CH}_{3}-\mathrm{H}_{4}$ folate and/or menadione slightly protects the enzyme against inhibition by AdoMet.

Measurement of the exchange of reducing equivalents between the folate substrates of methylenetetrahydrofolate reductase in the presence of NADPH and/or AdoMet

The effect of NADPH on the exchange of reducing equivalents between $\mathrm{CH}_{3}-\mathrm{H}_{4} \mathrm{PteGlu}_{1}$ and $\mathrm{CH}_{2}$ $\mathrm{H}_{4} \mathrm{PteGlu}_{6}$ was studied, and the data are shown in Fig. 5. 


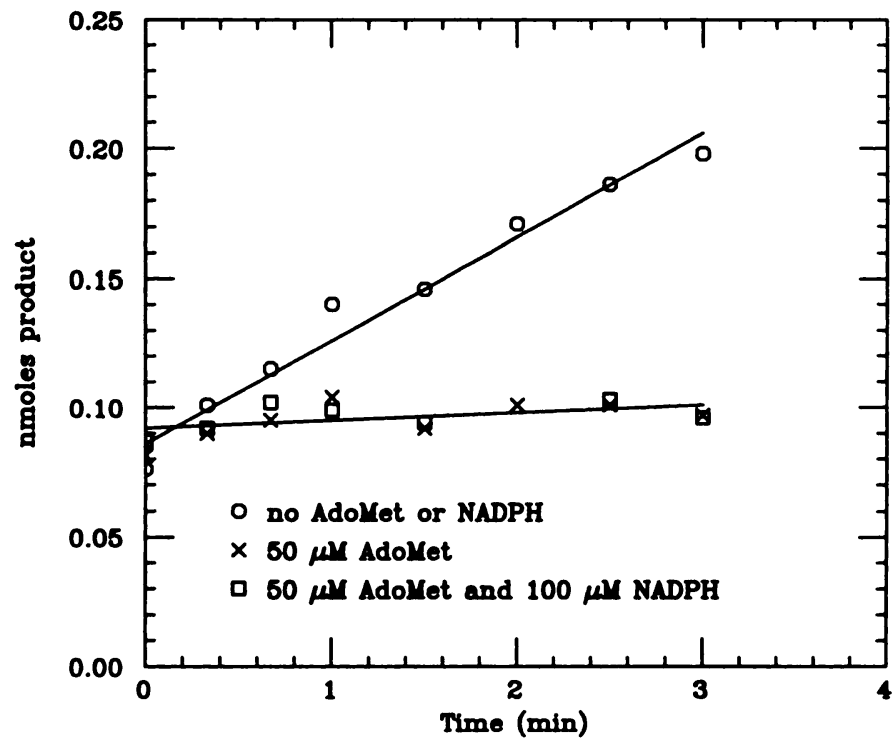

Figure 6. Effect of AdoMet and NADPH on the exchange of reducing equivalents between $\mathrm{CH}_{3}-\mathrm{H}_{4} \mathrm{PteGlu}_{1}$ and $\mathrm{CH}_{2}-\mathrm{H}_{4} \mathrm{PteGlu} 6$. Assay mixtures, $0.4 \mathrm{ml}$, contained buffer, $50 \mu \mathrm{M}$ tritiated $(6 R)-\mathrm{CH}_{3}$ $\mathrm{H}_{4} \mathrm{PteGlu}_{1}(68,000 \mathrm{dpm} / \mathrm{nmol})$, and $25 \mu \mathrm{M} \mathrm{CH}_{2}-\mathrm{H}_{4} \mathrm{PteGlu}_{6}$, and AdoMet and NADPH were added as indicated. [All experiments were conducted in $50 \mathrm{mM}$ potassium phosphate buffer, $\mathrm{pH} 7.2,0.3 \mathrm{mM}$ EDTA, and $10 \%$ glycerol (wt/vol).] Assays were initiated with the addition of enzyme, and were heat-quenched and performed as described before. Enzyme was preincubated for $10 \mathrm{~min}$ at $25^{\circ} \mathrm{C}$ in buffer containing the same amount of AdoMet and/or NADPH present in that assay. In this experiment the blanks were not subtracted. Percent activity (relative to the assay containing no added NADPH and AdoMet) was calculated from slopes: the reaction with no additions represents $100 \%$ activity; the reaction with $50 \mu \mathrm{M}$ AdoMet exhibited $12 \pm 5 \%$ activity; the reaction with $50 \mu \mathrm{M}$ AdoMet and $100 \mu \mathrm{M}$ NADPH exhibited $8 \pm 5 \%$ activity.

The rate of exchange between monoglutamate and hexaglutamate substrates is one-fourth as slow as that between the two monoglutamate substrates (data not shown). The curves of percentage of activity vs. NADPH concentration for the $\mathrm{CH}_{3}-\mathrm{H}_{4} \mathrm{PteGlu}_{1} / \mathrm{CH}_{2}-\mathrm{H}_{4} \mathrm{PteGlu}_{1}$ and $\mathrm{CH}_{3}$ $\mathrm{H}_{4} \mathrm{PteGlu}_{1} / \mathrm{CH}_{2}-\mathrm{H}_{4} \mathrm{PteGlu}_{6}$ exchange reactions are nearly identical. This implies that NADPH competes with $\mathrm{CH}_{3}-\mathrm{H}_{4} \mathrm{PteGlu}_{1}$ for reduction of the enzyme and that the nature of the second substrate does not alter the apparent inhibition of exchange by NADPH.

Although AdoMet and NADPH both individually inhibit exchange, previous studies have shown that in combination these may act as antagonists. Specifically, high concentrations of NADPH can decrease the inhibitory effect of AdoMet on the NADPH/menadione oxidoreductase activity of methylenetetrahydrofolate reductase (10). In Fig. 6 we show that a combination of NADPH $(100 \mu \mathrm{M})$ and AdoMet $(50 \mu \mathrm{M})$ leads to the same inhibition of exchange as does AdoMet $(50 \mu \mathrm{M})$ alone.

These studies establish that physiological concentrations of NADPH [200 $\mu \mathrm{M}$ (11)] and/or AdoMet [70 $\mu \mathrm{M}$ (12)] profoundly inhibit the $\mathrm{CH}_{3}-\mathrm{H}_{4}$ folate/menadione oxidoreductase activity (reaction 2) and the exchange of reducing equivalents between $\mathrm{CH}_{3}-\mathrm{H}_{4} \mathrm{PteGlu}_{1}$ and $\mathrm{CH}_{2}-$ $\mathrm{H}_{4} \mathrm{PteGlu}_{6}$ (reaction 3 ) catalyzed by methylenetetrahydrofolate reductase. The turnover number for NADPH/
$\mathrm{CH}_{2}-\mathrm{H}_{4}$ folate oxidoreductase activity is $5900 \mathrm{~min}^{-1}$, whereas the turnover number for $\mathrm{CH}_{3}-\mathrm{H}_{4} \mathrm{PteGlu}_{1}$ / menadione oxidoreductase activity is $300 \mathrm{~min}^{-1}$, and that for the $\mathrm{CH}_{3}-\mathrm{H}_{4} \mathrm{PteGlu}_{1} / \mathrm{CH}_{2}-\mathrm{H}_{4} \mathrm{PteGlu}_{6}$ exchange reaction, reaction 3 , is $72 \mathrm{~min}^{-1}$; thus, the uninhibited reactions that could lead to oxidation of $\mathrm{CH}_{3}-\mathrm{H}_{4} \mathrm{PteGlu}_{1}$ are significantly slower than the NADPH/CH $-\mathrm{H}_{4}$ folate oxidoreductase reaction. Intracellular NADPH and AdoMet should further reduce the velocity of these reactions in vivo, as they do in vitro.

We conclude that methylenetetrahydrofolate reductase will not provide a viable mechanism that can help the cell convert $\mathrm{CH}_{3}-\mathrm{H}_{4} \mathrm{PteGlu}_{1}$ into a better substrate for folylpolyglutamate synthetase. Despite its rather high $K_{\mathrm{m}}$ for $\mathrm{CH}_{3}-\mathrm{H}_{4}$ PteGlu $_{1}(6 \mu \mathrm{M})$ and its strong preference for $\mathrm{CH}_{3}-\mathrm{H}_{4} \mathrm{PteGlu}_{6}$ over $\mathrm{CH}_{3}-\mathrm{H}_{4} \mathrm{PteGlu}_{1}$ (6), methionine synthase must be responsible for the introduction of $\mathrm{CH}_{3}-\mathrm{H}_{4} \mathrm{PteGlu}_{1}$ into cellular metabolism. Because rapidly growing cells will require more exogenous folate than more slowly growing cells, this means that methionine synthase may be an attractive target for chemotherapeutic intervention.

This work was supported in part by U.S. Public Health Service grant GM 30885 from the National Institute of General Medical Sciences.

\section{REFERENCES}

1. Cichowicz, D. J.; Shane, B. Mammalian folyl- $\gamma$ glutamate synthetase. 2. Substrate specificity and kinetic properties. Biochemistry 26: 513-521; 1987.

2. Ross, J.; Green, J.; Baugh, C. M.; MacKenzie, R. E.; Matthews, R. G. Studies on the polyglutamate specificity of methylenetetrahydrofolate dehydrogenase from pig liver. Biochemistry 23: 1796-1801; 1984.

3. Kutzbach, C.; Stokstad, E. L. R. Mammalian methylenetetrahydrofolate reductase: partial purification, properties, and inhibition by S-adenosylmethionine. Biochim. Biophys. Acta 250: 459-477; 1971.

4. Vanoni, M. A.; Matthews, R. G. Kinetic isotope effects on the oxidation of reduced nicotinamide adenine dinucleotide phosphate by the flavoprotein methylenetetrahydrofolate reductase. Biochemistry 23: 52725279; 1984.

5. Vanoni, M. A.; Ballou, D. P.; Matthews, R. G. Methylenetetrahydrofolate reductase: steady state and rapid reaction studies on the NADPH-menadione oxidoreductase activities of the enzyme. J. Biol. Chem. 258: 11510-11514; 1983.

6. Matthews, R. G.; Ghose, C.; Green, J. M.; MatTHEWs, K. D.; DunlaP, R. B. Folylpolyglutamates as substrates and inhibitors of folate-dependent enzymes. Adv. Enzyme Regul. 26: 157-171; 1987.

7. Matthews, R. G. Methylenetetrahydrofolate reductase from pig liver. Methods Enzymol. 122: 372-381; 1986. 
8. Sumner, J.; Jencks, D. A.; Khani, S.; Matthews, R. G. Photoaffinity labeling of methylenetetrahydrofolate reductase with 8-azido-S-adenosylmethionine. J. Biol. Chem. 261: 7697-7700; 1986.

9. Matthews, R. G.; Ross, J.: Baugh, C.; Cook, J.; DAvis, L. Interactions of pig liver serine hydroxymethyltransferase with methyltetrahydropteroylpolyglutamate inhibitors and with tetrahydropteroylpolyglutamate substrates. Biochemistry 21: 1230-1238; 1982.

10. Jencks, D. A.; Matthews, R. G. Allosteric inhibition of methylenetetrahydrofolate reductase by adenosylmethionine: effects of adenosylmethionine and NADPH on the equilibrium between active and inactive forms of the enzyme and on the kinetics of approach to equilibrium. J. Biol. Chem. 262: 2485-2493; 1987.

11. Conway, J. G.; Kaupfman, F. C.; Thurman, R. G. Genetic regulation of NADPH supply in perfused mouse liver. J. Biol. Chem. 258: 3825-3831; 1983.

12. Hofrman, D. R.; Marion, D. W.; Cornatzer, W. E.; Duerre, J. A. S-Adenosylmethionine and S-adenosylhomocysteine metabolism in rat liver: effects of Lmethionine, L-homocysteine, and adenosine. J. Biol. Chem. 255: 10822-10827; 1980.

Received for publication August 27, 1987. Accepted for publication Seplember 23, 1987. 